\title{
PAST, PRESENT and THE FUTURE of IMMUNOTHERAPY (HYPOSENSITIZATION) in EXTRINSIC ATOPIC BRONCHLAL ASTHMA
}

\author{
Dr. ARMAN POLUMAN, MD*
}

DOI: http://dx.doi.org/10.5915/18-1-11733

Key Words: Immunotherapy. Bronchial Astlina.

Review article: Extrinsic atopic bronchial asihma, allergen imnunotherapy (hyposensitization)

\section{Abstract:}

In specific therapy of exirinsic bronchial astimatic cases, in which the atopic character is well identified with early type skin test posinvity against external allergens and increased serum $\lg E$ levels, the elimination of responsible allergens seems practically impossible. That is why the concept of allergen immunotherapy (hyposensitization) has been developed at the beginning of $201 \mathrm{~h}$ century.

In classical application, (conventional systemic immunotherapy) the dosage of aquens allergen solutions is increased at weekly inlervals unil the maximum caleruted dasage (MTD) is reuched. Then the therapy contimues at MTD jor 2.3 years.

In order 10 shorten the long lasting therapy "Rush" or "Cluster" Irealment regimes have been developed and depor extract contained preparates are widely used.

Clinically. The effect of immunolherapy is mustly observed by the improvement in symproms and signs. The decrease in reactivity in skin and bronchial provocation lesis and the effect of suppression are observed in some immuno-seralogic lesis.

On the other hand. with the use of non-antigenic naterials and modified allergen extracts helping lgE suppression in the extrinsic alopic bronchial asthma is believed 10 be an cffective. thrusting, low-costing and jast-recovering treatmem method in the years ahead.

\section{Introduction}

Bronchial asthma is a syndrome which has a relative high incidence in the population (2\% or total population) and which can occur by variely of stimuli. Despite the fact that the exact etiology of the syndrome is unknown. the imnunno-allergic factors are mosily incriminated. Inherited or aquired imbalance in adrenergic, cholinergic and probably purinergic (nonadrenergic and non-cholinergic) controls of aisway diameter, has also been implicated (9).

In ast hmatic individuals with hypereaclive bronchi; bronchocontriction may persist at subctinical levels (even when they are asymptomatic)(27). Allergic dis-

From: Deparmenl of Phlmonary Medicine, Asthma Alleryy Cenler, Sisli-Islanbul, Turkey.

Address all correspondence 10: Dr. Arman Poluman, Chest Physician (Pulmonary Fellow), Olpak

Pulmonary Diseases, Asthma Allergy Center, Osmanbey, Rumeli Cad. No. 55/l, Sisli-Islanbul, Turkey. eases are mostly due to the high degree of sensitivily developed against normally harmless substances. This hypersensitivity, probably developed by inherited predisposition, is commonty called as "atopy" (23). In atopic individuals hay fever, urticaria and allergic conjunctivitis are observed logether with bronchial ast.hma.

The mechanism of allergic reactions:

Early lype of hypersensitivity reaclions were first detected in early 1900's $(4,6)$ on skin of various bronchial asthmatic patients. Alopic individuals are capable of producing large amounts of reaginic antibodies which being homocylolrophic by nature, are fixed to the mast cells or basophils. This skin sensitizing aribody IgE, produced by submucosal plasma cells and lymph nodes in respiratory and gastrointestinal systems (30) was isolgted within past 20 years (12)

On re-exposure to the same allergen, the anigenanlibody reaction results in liberation of clsemical mediators which in turn trigger allergic reactions. 
Chemical mediators such as histamine, leucotriens. ECF-A elc, also cause vasodilatation, increased capillary permeability and bronchial smooth muscle contraction in bronchial asthma (13).

The atopic character in bronchial asthma is well determined by skin test positjvity and increased $\operatorname{lgE}$ antibody (25). Allergic skin lests are customarily performed to detect environmental allergens, (depending on patient's history) playing eliologic roles (28). The allergic character of a patient in bronchial asthuna is determined by the history, the relation of the syptoms to the environment, to seasonal and situational variations and his/her clinical course (26).

\section{Diagnoslic skin test procedure:}

In our censer, commercially available altergens are applied during skin tests. The prick test method, being usually safer due to the small amoun of antigen, is preferred (24). The skin is punclured $3-5 \mathrm{~cm}$. apart on the flexor aspects of the forearm by a darning needlc or by a lancet. Some clinicians also use the back or abdominal sites for punciure (31). A drop of glycerinepreparated test extract solutions is placed on each scratches and controls are performed simultaneously (the diluent-saline-as negative control and $0.1 \mathrm{mg} / \mathrm{ml}$. histamine chloride as positive control). In the intradermal test, a tuberculin syringe with short-bevel no. 26 (hypodermic) needle is used 10 inject $0.01-0.02 \mathrm{ml}$. of a lyophilized test extract of allergen solutions inta the skirı (32). International classifications are used to interpret all skin test results (20). On the orher hand, in some cases negative results arise from the use of original crude extracts. In order to oblain satisfactory result5, it is necessary to develop more purified. standardized and well-characlerized allergenic exiracl (3).

\section{The concept of immonotherapy:}

The complete avoidance (elimination) of allergens being mostly difficult in the therapy of extrinsic atopic bronclvial asthma. The procedure of hyposensitization was int.roduced for the treatment of pollenosis (hay fever) in 1911 (19). In this form of therapy (conventional systemic hyposensilization) the gradually' increasing subcuraneous aqueus allergen extraci solutions are used to increase the rolerance of the patient against offending allergens.

Depending on the palien I's reaction, injections continue at 1-7 days intervals up to the maximal tolerated dosage (MTD) or until a presel maximal dosage (usually 1.000.-10.000 times greater (han initial dosage). The altergen extracts are injected cither solely or by multiple regular intervals; perennial, pre-seasonal or coseasonal in pollen allergics (18).

The chances of satisfactory results are $90 \%$, if used regularly over a period of iwo to three years. Benenicial results reaching $90 \%$ can be obrained $(11,21,29)$. It is often necessary 10 give 20 or more injections before the maintenance dose is reached; therefore, some investi- gators have employed "rush" or "cluster" hyposensitization to titrate up to a higher dose more rapidly (17). Increased dosages are given every 1-2 hours, under close observation (hospitalization). Once the first intcrim maintenance dose is reached, the standard dose is then followed.

Local hyposensitization with direct stimulation of the shock organ has been used since 1951, inicially against bronchial asthma $(10,16,33)$. Numerous studies have described clinical effecis but wellcontrolled, double-blind investigations are necessary 10 uncover any potential effects of the treatment.

Following the development of allergen immunotherapy and its adapiation as a form of staudard praclice, a number of clinical and scientific questions were raised about its naturc. With the use of appropriate patient populations, doses of antigens and methods of evaluation, there exist clear demonstration of efficacy.

It is of considerable importance, in both clinical practice and irials, that the allergen immunocherapy resuls in a reduction but not elimination of syrnplonis. With the evaluation of allergen immunotherapy, studies on the mechanism of action are conducted by elinical investigators. It was later recognized that the term desensitizalion was nol appropriate, because even after continued therapy and apparent clinical improvement the patients remained reactive to allergens. The latter was also demonstrated by the continued presence of some symproms and immediate iype skin reactivity which led investigators to use the term hyposensitization therapy instead of desensitization therapy and morc recently the broader and less mechanistic term allergen immunotherapy (22).

The clinical improvemen following hyposensitization therapy has also been shown to be dose related and should be tailored to the need of the patient.

in order to fulinll the needs of an appropriate therapy it is extremely important 10 obtain a progress report of the symptons befor writing the treatment extract. The objective evaluasion of efficacy in the therapy lras been the response 10 bronchial provocation tests in clinical observation $(1,3)$.

\section{Immunologtc efficacy parameters:}

Most of the scientific knowledge on the methanism of action of allergen immunotherapy is yet very recent and insufficient. Therefore, it seems appropriale 10 try to fully understand immunologic mechanisms responsible for the results of immunotherapy and to hope that the principles learned will allow the evaluation of efficacy by techniques simpler than full-scale clinical studies. Immunologic studies appear to strive to the goal but linal answers have yet to be obtained. As noted esrlier, immunization by curren methods sends to induce a parcial degree of suppression of $\mathrm{lgE}$ antibody responses. The mechanism by which this occurs in human beings has not yet been worked oul.

But parallel experiments in mice strongly suggest 
that suppression of IgE antibodies comes about through the stimulation of supressor $T$-cells (specific for IgE antibodies toward the antigen which the animal has received by parenteral injections). Although hyposensitizalion is being employed now for 70 years, it has not been possible to clarify the immunological mechanisms or to establish any certain effect parameters (21).

Complete decrcased levels of either serum toral lgE. serun specilic IgE (SS IgE) or boll,, was not observed during the allergen immunotherapy of extrinsic atopic bronchial asthma (18). Following the application of allergen immunotherapy, serum lolaliy IgG. SSIgG and $S S \lg G / S S \lg$ E ratio usually increases to rclatively higher levels (8).

Some trials indicared reduced basophilic histamine relcase (cell sensitivity index) during hyposensitization (15). Studies on lymplrocyte accivity have shown an increase in T-suppressor cells and a posi-treatment reduction on lymphoblast transformation (LT), mitogenic factor(MF) and in migtation inhibitory factor (MIF) $(5,7)$. On the other hand, during immunotherapy it has been sliown that some serum specific suppressor substances were also particularly detected against $\operatorname{lgE}$ (14). The inhibited listamine-induced suppressor factor (HSF) which is released from T-suppressor cells (previously round as inhibited) gradually increased following the allergen immunotherapy in the atopic individuals (2).

\section{Receni developmenss in immunotherapy:}

It has been the goal of many investigators to improve the preparations used in allergen immunotherapy which will aid to reduce the number of injections and increase the therapeutic safety. in order to reduce the number of injeciions slow-release preparacions such as oil-emulsions, alum-precipilation and tyrosine adsorption ect. have been investigated. Emulsions in oil, resuleing in unaccepiable local reacion. fail to provide adequale efficacy and dropped from consideration because of potential carcinogenicity

Alum-precipitation requiring a course of $71010 \mathrm{in-}$ jections appears to be reasonably efficacious and the incidence of symptoms following the shots is reduced. To prevent the larger local reactions the extract is prepared with pyridine but, questlons arise as to the eflicacy of treatment when this organic solvent is used (!7).

In L-tyrosine adsorbed depot extracts the release of antigens is slow, but the efficacy was diminished compared to other depot extract (18). Recent advances in immunotherapy clearly show us that when modified allergens are used the allergenicity is reduced while still retaining effect of immunogenicity. The allergenicily is defined as the ability to clicit an IgE mediated response where the immunogenicity being the abilicy the induce an $\lg G$ antibody response.

If the allergenicity can be reduced by polymeriza- tion at monomeric ansigens (due to the concealed antigenic determinants in the polymer) than the amount of allergen administered could be increased. In this form, the immunogenicity should be retained because the antigenic determinants are still available for processing by macrophages and initates an $\lg G$ antibody response. An equal weighl of polymeric antigens would have a lower molecular concentration and decreased opportunity to bridge IgE antibody molecules on masi cells. The selection of allergens included in the treatment extract is based on clinical history and the allergy skin tests (22).

A different way to reduce allergic reactions is 10 modify the allergen by various cliemical treatments. The altergenicity is then greatly reduced, while maistaining the necessary anligenicily required for the desired immunologic responses. One of the methods used 10 modify allergens is a formaldehyde or glutaraldehyde ireatment. Formaldehyde-treated materials have been referred as allergoids, a term derived from allergen as toxoid from toxin. Indeed. allergoid materials do slow less allergenic potential by more than hundred folds. The patient can be immunized with fewer doses instead of increased doses given by injection.

Allergoids, appearing to be an improvement over present techniques of immunization, are still under trial and not yet available to the practicing physician. There also exist two modified allergens to mention for parenteral immunization. The first modified material combines extraction with the organic solvent, pyridine, followed by alum-precipitation. The secons material is obtained by the treatment of allergens with glutaraldehyde; followed by adsorp. lion to suspensions of L-thyrosine (18).

\section{The future of Immunotherapy:}

Immunologic comparisons with standard aslergenic extract are not available currently and the method requires further evaluation. Morcover, new area accumulating a grear interest in terms of immunologic management of allergies is 10 be mensioned despite its unknown practical value.

Urea-denaturated materials are non-antigenic and stimulate litrle or no $\lg G$ antibody response but produce suppression of lgE synthesis. To date. 10 degree of suppression of $\mathrm{lgE}$ synthesis has been 100 small to be clinically useful, but deserves further investigations.

Other methods of inducing $T$ cell suppression have also been tried. Polyethylene glycol-substitured allergens have been offered as a way of either producing stimulation of suppressor T-cell or inducing 5ome other suppression mechanisms of $\mathrm{lg}$ E synthesis. It is also possible to induce a $B$ cell tolerance in animals by adding shorl chained constiluents to antigens (principally a copolymer of D-Glutamic acid and D.Jysine).

It has been suggested that suppression of anlibody 
responses can be induced by the administration of allergen-antibody conjugate and experiments in animals have been producing interesting results in Ihis direction (18).

\section{Conclusion:}

Controlled observations have confirmed many, but not all, of the empirical observations on the clinical effects of immunization with allergenic extracts. These immunologic methods provide valuable but yet imcomplete clues for the mechanisms of immunization. Such observasions do however. provide clues for betler ways of immunizing patients. Shorter courses of immunization with less side effects do also appear 10 be possible in the near future.

We hope to see reliable improvemencs in immunotherapy that will further shorlen the course of immunization, eliminate allergic side effects and improve efricacy in the years ahead.

\section{References}

I. Aus, K.: Hyposensilizalion in housc dust allergy asthma. A double-blind sady wilh evaluacion of the ef fect on bronchial liypersensitivicy to house dust. Acta Paedit. Seand. 60, 264. 1971.

2. Beer, D.J. and Rocklin, R.E.: Hislamine-induced supressor(ell activily. J. Ail. Clin. Immurol, 73, 439, 1984.

3. Berg. T.. Norvall. S.L. and Lanner, Ao.:Clinical siudics of a limothy pollen extrucl. Desensislzation therapy wilh a purified limolhy pollen presaralion compared to a crude ilmollyy pollen txiraci.l. Resulis of tesis invivo. Irt. Are. Nler. 63, 266, 1980.

4. Blackley. G.H.: Experimental rescarches on the eluses and nalure of Calarrhus acsiveus (Hay rever and asthma). Bailliere, Tindall and Cox Lid. London, 1873. Ind Ed.

5. Cannanica, G.W., Mingari, M.C., Melioli, G., Calombatti, M. and Morclta, L.: Imbalances of 'T cell subpopulations in patients with aropic diseases and $\mathrm{rffecl}$ of specific immonotherapy.J.Immunol. 123, 26\%9, 1979.

6. Coca, A.F. and Cooke. R.A.: On the classification of the phenomena of hypersensitiveness. 5.1 mmunol. \$, 163, 1923.

7. Evans, R., Pence, H., Kaplan, H, and Rocklin, R.E.; The cffecl of immunosherapy on hunjoral and cellular responses on ragweed bay fever. J.Clin.Invesi, 57, 1378, 1976.

8. Foucard, T. and Johassson, S.G.O.: Alletgen-spceiric lgE and $\lg G$ antibodics in pollen allervic thildren given immunotherapy for 2-6 yeurs. Clin. Allergy 8, 249. 1978.

9. Gleich, G.J. and Tomasi, T.B.Jr.: Gencral inuroduction to immunology. In Bronchial asthms: Mechanisms and herapeutics. Wciss. E.B. and Segal, M.S. (eds.), Litle, Brown and Co., Bosion. 1976, p.67.

10. Herxlseimer, H.: Bronclyial hyposinsitization and hyposensilizalion in man. In1.Arc.All.App.Immunol. 2, 40, 1951.

11. Hunı, K.J., Sobarka, A.K., Amadin, F.J., Valentine, M.D., Benton, A.W. and Lichenstein. L.M.: A conirolled trial of immunotherapy in insect hypersensilivily. New Eng.l. Med. 299, 257, 1978.

12. Ishizaka, K., Ishizaka. T. and Hornbrook, M.M.: Phyico themical properties of human reaginic anibody: IV. Pres. trec of unique imstunoglobulin as a carrier of reaginic attivlis. J.Imenunal. 97, 75, 1966.
13. Kulincr, M. and Austen, K.F.: The sequence of biochemical events in the anligen-induced release of chemical mediators from sensigized human lung lissue. J.Exp.Mod. 138. 1077, 1973.

14. Kar., D.H.: Regulation of the lyE system: Experimentul and elincal aspects. Aliergy 39. 81. 1984.

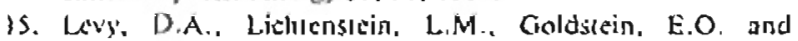
Ishazaka, $K$.: Immunologic and cellular changes accumpanying the therapy of pollen alietgy'. J.Clin. Invest, 50, 360. 1971.

16. Malhews, K.P., Bayne, N.K. and Banas, J.M.: A contralled study of inlranasal immuncherapy with polymerized rabweed antigen (absI.). J.AlI. Clin. Immunol. 65, 191, 1980.

17. Mischler, T.W., O'Brien, W.M., Rugloski, R.J., Fenwick, M., Patombo, G., Bciquc, C., Freedman, S.O., Grant, R.S.. Hargreave, F.E., Kmglı, A., Schulz, J.I., Wessnagel, J. and Underdorum. B.f.: A melticlinic trial witl Bluceraldchyde modified tyrosine-adsorbed ragweed pollen immunotherupy (Pollinex ). Curr. Ther. Rexeurch 29.745. 1981.

18. Nornán. P.S.: An overvitw or inununuthcraps: Implicalions for the furure. J.All.Clin. Imriun. 65, 87, 1980.

19. Noon, L.: Prophylacilc inoculalion against hay fever. Lancel I. 1572.1911.

20. Pallerson, R.: Allergic discases. Diagnosis and management. J.B. Lippincoll Co. Philadephia 1972, g.77.

21. Pullerson. R.. Lieberman, P., Irons. J.S., Pruzansky. J.J.. Melam, H.L., Metzger, W.J. and Zeiss, C.R.: Immuno. therapy, In Allergy, principles and practice. Middleton, E.. Reed, C.E. and Ellis, E.F. \{eds.). C.V. Mosby Co.. SI. Louis 19̄79. 0877.98 .

22. Paererson, R.; Allergen immunotherapy wilh modilied allergens. J.All.Clin. Immunal. 68. 85, 1981.

2]. Pepys, J.: Alopy. [ı Clinical aspects of immunology., Gell, P.G.H. and Coombs, R.R.A. (eds.). Blackwell Scientific Pub. Oxford 3rd. ad. 1975, p. 877.

24. Pepys, J.: Skin icsting. Br.J.Hosp. Mcd. 14, 412, 1975.

25. Poluman. A.: The investigation of the immunosupressive effect of cor ucoscriods on extrinsic alopic bronchial asthma. Post-graduate itresis. University of Istanbul. Cerrahpasa Medical Faculiy, Jslanbul, 1981 (Turkish).

26. Poluman, A.: The investigation of the contlation in.tween loe unam.nestic and clinical findings and of skin lists und serum lolally IgE (PRIST) in exirinsic allergic (alopic and non-alopic) bronchial asthma. Solunum Derg. (Turkısh) in nress.

27. Saygin, R., Yenel, F., Erk(Corapcioglu) M, and Poluman. A.: In effectiveness of venillation in asthmalle remission. Scicnilije and Technical Rescarch Council of Turkey. Medical Siudy Group Publicaion N. 558 TAG Scries No. 28, 231, 1983 (Turkish).

28. Slavin, R.G.: Skin tosts in the diagnosis of allergies of the immediate type. Med.Clin. N.Amer. 98. 65, 1974.

29. Sorenson, H.J.: The clinical value of hyposensitization in bronchial asthma and allergic rhinilis. Ugeskr. Laeg. $138 . \mathrm{I}$. 1976.

10. Tada, T. and Ishizaka, K.: Distribulion of the lgE forming cells in lymphoid rissues of the human monkey. J. Immunol. 104, 377, 1970.

31. Voorhors1, R. and ven Krickin, H, Alopic skin test recvaluated. J. Perfection of techiqut. Ann. Allergy 31, 137. 1973.

32. Wittig. H.J. and Delliot, J.D.: Volidily of the alkergy skin Iest. J. Louisiana S. Med, Soc, 131, 191, 1979.

33. Wortmann, F.: Oral hyposensitization. Altergos. Immunopathol. Suppl. 3. 65, 1976. 